\title{
The Role of Secreted Frizzled Related Protein 4 (sFRP-4) in Regulating Oestradiol-Induced Growth of the MCF-7 Breast Cancer Cell Line
}

\author{
Sally McLaren ${ }^{1}$, Frank Arfuso ${ }^{2,5}$, Nik Zeps ${ }^{1,3,4}$ and Arun Dharmarajan ${ }^{2,5,{ }^{*}}$ \\ ${ }^{1}$ School of Surgery and Pathology and Laboratory Medicine, The University of Western Australia, 35 Stirling \\ Highway, Crawley, Western Australia 6009 \\ ${ }^{2}$ School of Anatomy, Physiology and Human Biology, Faculty of Life and Physical Sciences, 35 Stirling \\ Highway, Crawley, Perth, Western Australia 6009 \\ ${ }^{3}$ St John of God HealthCare, Subiaco, Western Australia 6008 \\ ${ }^{4}$ School of Surgery, The University of Western Australia, 35 Stirling Highway, Crawley, Western Australia \\ 6009 \\ ${ }^{5}$ School of Biomedical Sciences, Faculty of Health Sciences, Curtin University and Curtin Health Innovation \\ Research Institute (CHIRI) GPO Box U1987 Perth, Western Australia 6845
}

\begin{abstract}
The Wnt signalling pathway is involved in regulating cellular proliferation and differentiation, and aberrant activation has been described in several cancers including breast. Oestradiol up regulates Wnt pathway gene expression, and thereby activates the Wnt signalling pathway. We used the oestrogen-responsive breast cancer cell line MCF-7 to examine the effects of secreted frizzled related protein 4 (sFRP-4) on oestradiol-induced growth, including gene expression of the Wnt signalling pathway genes Frizzled Receptor, Wnt-10b, and $\beta$-catenin. We demonstrate here that SFRP-4 inhibits oestradiol-induced cell growth in the MCF-7 cell line and also down regulates oestradiol-induced expression of selected Wnt signalling genes including $\beta$-catenin. We propose that SFRP-4 is a potent inhibitor of the Wnt signalling pathway and may negatively regulate oestradiol-mediated proliferation in human breast cancer cells.
\end{abstract}

Keywords: Breast cancer, sFRP4, Wnt signalling, oestradiol, $\beta$-catenin, cellular proliferation, growth inhibition.

\section{INTRODUCTION}

Reproductive tissues undergo cycles of hormone driven growth followed by regression involving apoptosis. A novel clone expressed in the rat corpus luteum undergoing regression was isolated by our laboratory [1, 2] and this gene, termed secreted Frizzled Related Protein-4 (sFRP-4), was shown by Northern blot analysis and in situ hybridization to be highly expressed in regressing ovarian, mammary gland, and ventral prostate tissues after hormone withdrawal [2]. sFRP-4 expression is undetectable in the resting mammary gland of the rat until involution, when there is a greater than ten-fold increase in sFRP4 expression [2].

sFRP-4 is related to the frizzled (FZ) family, which functions as a receptor for the ubiquitous family of secreted Wnt signalling molecules. Based on amino acid sequence analysis, the FRP CDNA is believed to encode for the frizzled-like, cysteine-rich domain but not the seven-pass transmembrane domain seen in

${ }^{*}$ Address correspondence to this author at the School of Biomedical Sciences, Faculty of Health Sciences, Curtin University and Curtin Health Innovation Research Institute (CHIRI) GPO Box U1987 Perth, Western Australia 6845; Tel: +61 89266 9867; Fax: +61 89266 1715;

E-mail: a.dharmarajan@curtin.edu.au other FZ family members [3]. Thus, it has been proposed the FRPs are secreted proteins that compete for Wnt ligand binding, as well as forming a dominant negative interaction with the $F Z$ receptor to modulate the Wnt-frizzled signal transduction pathway [4].

Northern blot analysis of a variety of human tissue RNA samples has shown that there are high levels of expression of sFRP-4 in ovary, prostate, testis, spleen, and thymus, but not in the colon, small intestine, and peripheral blood leukocytes. To date, only one published study has examined SFRP-4 expression in human breast tissue and breast tumours using in situ hybridization [5]. They identified an up regulation of sFRP-4 mRNA in in situ and invasive ductal breast carcinomas compared with the normal breast parenchyma [5]. The induction of sFRP-4 expression in the in situ carcinoma, the earliest form of breast tumour, suggests its expression may be an early neoplastic event [5]. Oestrogen has been implicated as a potential regulating factor of SFRP-4 due to the predominant expression of SFRP-4 during the oestrogenic phase of the endometrial cycle [5].

SFRP-4 expression has been demonstrated in prostate carcinomas compared with normal prostate 
tissue [6]. Membranous expression of sFRP-4 was associated with good patient prognosis, highlighting its potential as a prognostic marker and suggesting that sFRP-4 may be involved in counteracting unregulated growth in hormone-responsive cancers [6]. More recently, sFRP4 expression was associated with a better prognosis in ovarian cancer patients and acts through inhibition of the Wnt signalling pathway $[7,8]$. It was found that over expressing SFRP4 in breast cancer cell lines that were resistant to cisplatin rendered these cells sensitive to treatment [7]. Furthermore, there was a positive association between decreased sFRP4 expression and increased severity of tumour seen in patient tissue microarrays [7]. In the present study we examined the role of SFRP-4 on the growth of the breast cancer cell line MCF-7, specifically examining whether it was able to modulate oestradiol-induced cell growth.

\section{MATERIALS AND METHODS}

\section{Cell Culture}

The human breast cancer cell line, MCF-7 (donated by Dr Jacky Bentel), was grown in RPMI 1640 (Gibco) supplemented with $10 \%$ foetal bovine serum (FBS) (JRH Biosciences), 2mM L-glutamine (L-glut) (Gibco), $2 \mathrm{mM}$ penicillin (Gibco), and $2 \mathrm{mM}$ streptomycin (Gibco). Cells were cultured at $37^{\circ} \mathrm{C}$ with $5 \% \mathrm{CO}_{2}$. Trypsinised MCF-7 cells were seeded onto 6 -well tissue culture plates (Sarstedt) at a final concentration of $5 \times 10^{4}$ cells per well for all experiments. Cells were incubated overnight to allow attachment to the well surface. Seeding day was allocated as day one.

\section{Oestradiol Treatment}

Phenol red-free (PRF) RPMI medium (Gibco) supplemented with $5 \%$ charcoal-stripped serum (Trace), $2 \mathrm{mM}$ L-glutamine (L-glut), $2 \mathrm{mM}$ of penicillin and streptomycin were added to the cells on day two to starve the cells of oestrogens. $100 \mathrm{nM}$ of $17 \beta$-oestradiol $\left(E_{2}\right)$ (Sigma) were added to the cells on day four together with fresh PRF charcoal-stripped growth medium. Cells were incubated with $E_{2}$ for 72 hours.

\section{sFRP-4 Conditioned Media Experiments}

$\mathrm{NIH}: 3 \mathrm{~T} 3$ cells (derived from embryonic mouse fibroblasts and obtained from ATCC, Virginia, USA) were virally transfected with the SFRP-4 gene as previously described (Lacher et al. 2003). 3T3 cells were maintained in RPMI 1640 supplemented with $10 \%$ FBS, $2 \mathrm{mM}$ L-glut, $2 \mathrm{mM}$ penicillin, and $2 \mathrm{mM}$ streptomycin. The sFRP-4 conditioned media were aspirated and used in the SFRP4 treatment experiments. SFRP-4 protein concentration in the conditioned media was determined using a standard Bradford assay. Cell media were aspirated from untransfected 3T3 cells to use as a control for SFRP-4 treatment.

\section{Determining sFRP-4 Dose}

Protein isolation was performed on the SFRP-4 transfected (NIH:3T3+sFRP-4) and untransfected 3T3 cell media to determine the total protein concentration of the media and, thus, approximate a dose of total protein for conditioned media treatment.

$10^{6} \mathrm{NIH}: 3 \mathrm{~T} 3$ and $\mathrm{NIH}: 3 \mathrm{~T} 3+\mathrm{sFRP}-4$ cells were seeded in separate T-25 culture flasks in RPMI, $10 \%$, FBS, and $2 \mathrm{mM}$ penicillin and streptomycin antibiotics and left to adapt to the culture flask overnight. To ensure the conditioned media for treatment were not dominated by the proteins present in FBS, media were replaced with serum-free media and the cells cultured for 72 hours. Protein was extracted from the media following three days of culture. Medium was passed through a $0.45 \mu \mathrm{m}$ filter and two $3 \mathrm{ml}$ aliquots of each sample were transferred to $15 \mathrm{ml}$ falcon tubes. The unused media were stored at $4^{\circ} \mathrm{C}$ for future treatments. $12 \mathrm{ml}$ of ice-cold acetone were added to each of media samples, the samples vortexed and then incubated at $20^{\circ} \mathrm{C}$ for 60 minutes. Samples were then centrifuged at maximum speed at $4^{\circ} \mathrm{C}$ for 10 minutes to pellet the protein precipitate. The supernatant was removed and discarded and the acetone evaporated from the samples by leaving the tubes open at room temperature for 30 minutes. The protein pellet was then re-suspended in $50 \mu \mathrm{l}$ of $0.01 \mathrm{X}$ PBS, the two samples pooled together, and an aliquot set aside for the Bradford protein assay to determine total protein concentration.

A $350 \mu \mathrm{l}$ dose of conditioned media from both transfected and untransfected cells was used for MCF7 treatment. The protein concentration of media samples was determined by Bradford protein assay, and this dose represents approximately $1.3 \mathrm{mg}$ of total protein for untransfected cell media and $1.6 \mathrm{mg}$ for $3 T 3+$ sFRP-4 cell medium. The $300 \mu \mathrm{g}$ difference between these two samples potentially represents the amount of SFRP-4 present in the $3 \mathrm{~T} 3+\mathrm{sFRP}-4$ culture medium. The volume of conditioned media was kept constant for the MCF-7 treatments to control for the presence of depleted media in culture. 


\section{sFRP-4 Treatment}

PRF RPMI medium supplemented with $5 \%$ charcoal stripped serum, $2 \mathrm{mM}$ L-glutamine, $2 \mathrm{mM}$ penicillin and streptomycin was added to the MCF-7 cells on day two. $350 \mu \mathrm{l}$ of SFRP-4 conditioned media were added to the treatment cells on day four together with $2 \mathrm{mls}$ of fresh PRF charcoal stripped growth medium. $350 \mu$ l of 3 T3 untransfected cell media were added to the control cells together with $2 \mathrm{mls}$ of fresh PRF charcoal stripped media, to account for the addition of depleted growth media on the cells. Cells were incubated with sFRP-4 for 72 hours.

\section{Combined Oestradiol and SFRP-4 Treatment}

A combined $E_{2}$ and SFRP-4 treatment was undertaken to investigate whether SFRP-4 can counteract oestradiol-induced proliferation of MCF-7 cells. These were performed in substantially the same way as described above except $350 \mu l$ of sFRP-4, conditioned media were added to the cells on day four together with $2 \mathrm{mls}$ of fresh PRF charcoal stripped growth medium and $100 \mathrm{nM} \mathrm{E}_{2}$, and then incubated for 72 hours. Controls received $350 \mu$ l of $3 T 3$ untransfected cell media together with $2 \mathrm{mls}$ of fresh PRF charcoal stripped media and $100 \mathrm{nM} \mathrm{E}_{2}$.

\section{Cell Proliferation Assay}

Following the 72 hour treatments of $E_{2}$, sFRP-4 conditioned media, and combined $\mathrm{E}_{2}$ and SFRP-4 conditioned media, cells were trypsinised and counted using a haemocytometer (Nebauer Improved, Crown Scientific). To ensure accurate counting, each sample ( $n=3$ for each sample) was loaded into the haemocytometer twice, and in each load, three representative 25 -square areas were counted, resulting in six counts per sample.

\section{Real-Time RT-PCR}

RNA was extracted from MCF-7 cells using TRI REAGENT according to the manufacturer's instructions (Molecular Research Centre). RNA concentration was determined from the absorbance at $260 \mathrm{~nm}$. $1 \mu \mathrm{g}$ of each RNA sample was DNase-treated using the DNAfree ${ }^{T M}$ kit (Ambion) according to manufacturer's protocol to remove any genomic DNA contamination. RNA was reverse transcribed into cDNA, using M-MLV reverse transcriptase (Promega) according to a standard protocol. Point mutant \#M3682 (Promega) was added to each sample. Clean-up for the reverse transcription reaction samples was completed using the
Ultraclean PCR Clean-up DNA purification kit (MO BIO) in accordance with manufacturer's protocol.

The real-time PCR reaction mix consisted of $5 \mu$ of $\mathrm{iQ}^{\mathrm{TM}}$ SYBR $^{\circledR}$ Green Supermix (BIORAD), $1 \mu \mathrm{l}$ each forward and reverse primers $(5 \mu \mathrm{M})$ (table 2.1), $2 \mu \mathrm{l}$ of $\mathrm{dH}_{2} \mathrm{O}$, and $1 \mu \mathrm{l}$ of cDNA to make a total reaction volume of $10 \mu \mathrm{l}$. $1 \mu \mathrm{l}$ of water was added instead of cDNA in negative (no-template) controls. Samples were measured in duplicates. The PCR reaction was performed on a Rotor-Gene RG-3000 (Corbett Research). Cycling conditions varied for each gene and are detailed in Table 1. A fluorescence measure was taken at the end of each cycle to form an amplification curve. The starting amount of cDNA template was extrapolated from $\mathrm{Ct}$ values and was the basis for calculating and comparing mRNA expression for each sample. Quantitation values were normalized to the housekeeping gene L-19, determined by the absorbance reading at $260 \mathrm{~nm}$. Amplified product obtained from the PCR reaction was run on a $2 \%$ agarose gel to determine product size.

\section{Immunoblotting}

Protein was extracted from MCF-7 cells by incubating with $100 \mu$ l of RIPA buffer for 30 min on ice. The samples were centrifuged at maximum speed for 5 minutes at $4^{\circ} \mathrm{C}$. The concentration of the protein supernatant was determined by BSA assay. $50 \mu \mathrm{g}$ of protein were separated by SDS gel electrophoresis on a $10 \%$ polyacrylamide gel, and then transferred onto a Hybond ${ }^{\mathrm{TM}}-\mathrm{C}$ nitrocellulose membrane (Amersham). Membranes were blocked in $0.5 \%(\mathrm{v} / \mathrm{w})$ gelatin solution for 30 minutes at $37^{\circ} \mathrm{C}$. To detect SFRP-4 protein expression, rabbit polyclonal anti-rat sFRP-4 (Upstate Biotechnology, USA) was applied to the membranes. The human and rat proteins share 90\% homology (Pubmed library: rat: NP_445996, human: NP_003005). The sFRP-4 antibody was diluted 1:250 in TBST-0.05\% and incubated with the membrane overnight at $4^{\circ} \mathrm{C}$ with shaking. Membranes were then incubated with HRP-conjugated goat anti-rabbit $\operatorname{lgG}$ (DAKO) diluted 1:5000 for $1 \mathrm{~h}$ at room temperature. All signals were detected using enhanced chemiluminescence system (SuperSignal ${ }^{\circledR}$ West Pico Chemiluminescent substrate PIERCE).

The activity of the Wnt signalling pathway was measured by quantifying the levels of dephosphorylated $\beta$-catenin. Mouse anti-active $\beta$ catenin antibody (Upstate ${ }^{\mathrm{TM}}$ ) was diluted 1:330 in TBST- $0.05 \%$ and incubated with the membrane 
Table 1: Gene Primers and Thermocycling Conditions for Genes Examined

\begin{tabular}{|c|c|c|c|c|}
\hline Gene & Primer Sequence & Cycling conditions & Cycles & Product Size \\
\hline sFRP-4 & $\begin{array}{l}\text { F 5' TCT GTA CCA AAG GGC AAA 3' } \\
\text { R 5'ACC ACC GTT GTG ACC TCA TT 3' }\end{array}$ & $\begin{array}{l}94^{\circ} \mathrm{C} \text { for } 3 \mathrm{mins} \\
94^{\circ} \mathrm{C} \text { for } 30 \mathrm{sec} \\
60^{\circ} \mathrm{C} \text { for } 30 \mathrm{sec} \\
72^{\circ} \mathrm{C} \text { for } 30 \mathrm{sec}\end{array}$ & 45 & $110 \mathrm{bp}$ \\
\hline $\mathrm{Fz}-4$ & $\begin{array}{l}\text { F 5' GAC AAC TTT CAC ACC GCT CA 3' } \\
\text { R 5' GGC AAA TCC AAA TTC CTT CA 3' }\end{array}$ & $\begin{array}{l}94^{\circ} \mathrm{C} \text { for } 3 \mathrm{mins} \\
94^{\circ} \mathrm{C} \text { for } 30 \mathrm{sec} \\
55^{\circ} \mathrm{C} \text { for } 30 \mathrm{sec} \\
72^{\circ} \mathrm{C} \text { for } 30 \mathrm{sec}\end{array}$ & 45 & $178 \mathrm{bp}$ \\
\hline Wnt-10b & $\begin{array}{l}\text { F 5' TGG GCC GGG CCA TCT TCA TT 3' } \\
\text { R 5'GGC TGC CAC AGC CAT CCA AC 3' }\end{array}$ & $\begin{array}{l}94^{\circ} \mathrm{C} \text { for } 3 \mathrm{mins} \\
94^{\circ} \mathrm{C} \text { for } 30 \mathrm{sec} \\
60^{\circ} \mathrm{C} \text { for } 30 \mathrm{sec} \\
72^{\circ} \mathrm{C} \text { for } 60 \mathrm{sec}\end{array}$ & 45 & $204 \mathrm{bp}$ \\
\hline$\beta$-catenin & 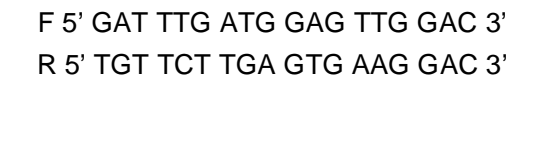 & $\begin{array}{l}94^{\circ} \mathrm{C} \text { for } 3 \mathrm{mins} \\
94^{\circ} \mathrm{C} \text { for } 30 \mathrm{sec} \\
52^{\circ} \mathrm{C} \text { for } 30 \mathrm{sec} \\
72^{\circ} \mathrm{C} \text { for } 30 \mathrm{sec}\end{array}$ & 45 & $218 b p$ \\
\hline
\end{tabular}

overnight at $4^{\circ} \mathrm{C}$ with shaking. Membranes were then incubated with HRP-conjugated rabbit anti-mouse IgG (DAKO) diluted 1:5000 for $1 \mathrm{~h}$ at room temperature.

Membranes were stripped of antibody by incubating with stripping buffer for 30 minutes at room temperature, and then re-probed with the housekeeping protein $\beta$-actin. The membranes were blocked in skim milk powder for $30 \mathrm{~min}$ at $37^{\circ} \mathrm{C}$ followed by incubation with the $\beta$-actin antibody (Sigma) (1:5000) overnight at $4^{\circ} \mathrm{C}$ with shaking. Membranes were then incubated with secondary HRP-conjugated rabbit antimouse $\lg G(1: 10000)$ for $1 \mathrm{~h}$ at room temperature.

Western blots were quantified using Scion Image software by analysing the pixel density between the control and treatment samples. Data were normalised by dividing quantitation values by the $\beta$-actin quantitation values to account for any error in loading or variation in protein concentration.

\section{Statistical Analysis}

Data are represented as mean values \pm SEM. Differences between groups were analysed by an unpaired two-tailed $t$-test with equal variances, and were considered statistically significant when $p<0.05$.

\section{RESULTS}

We used a cell counting method to establish proliferation rates of MCF-7 cells grown in culture. When MCF-7 cells were treated with $17 \beta$-oestradiol for a 72 hour period, we observed a $25 \%$ increase in cell number compared to the ethanol control $(p<0.001$; Figure 1A). When MCF-7 cells were incubated with sFRP-4 alone, there was a statistically significant but relatively modest $15 \%$ reduction in MCF- 7 cell number by comparison with untreated cells $(p=0.003$; Figure 1B). Finally, when sFRP-4 was added in combination with oestradiol, we observed that the increase in the number of cells we might have expected was reduced about one half when compared to oestradiol treatment alone $(p<0.001$; Figure 1C). Taken together, these results suggest sFRP-4 antagonises MCF-7 cell proliferation both with and without oestradiol driving that growth.

To ensure that oestradiol was not affecting endogenous SFRP-4 levels, we examined both mRNA and protein expression of SFRP-4 in MCF-7 cells for all treatments. No statistical difference was observed between either endogenous sFRP-4 mRNA or protein levels in any of our experiments (Figure 2).

Since oestradiol has been previously described as stimulating expression of Wnt pathway associated genes in MCF-7 cells, and we had observed that sFRP4 could suppress oestradiol-induced cellular proliferation, we undertook to quantitate expression of these genes to determine if SFRP-4 was suppressing their expression. We selected Wnt-10b for RT-PCR analysis because this has been previously associated with oestradiol-induced Wnt pathway stimulation [9-11]. All treatments were for 72 hours and, in all PCR 


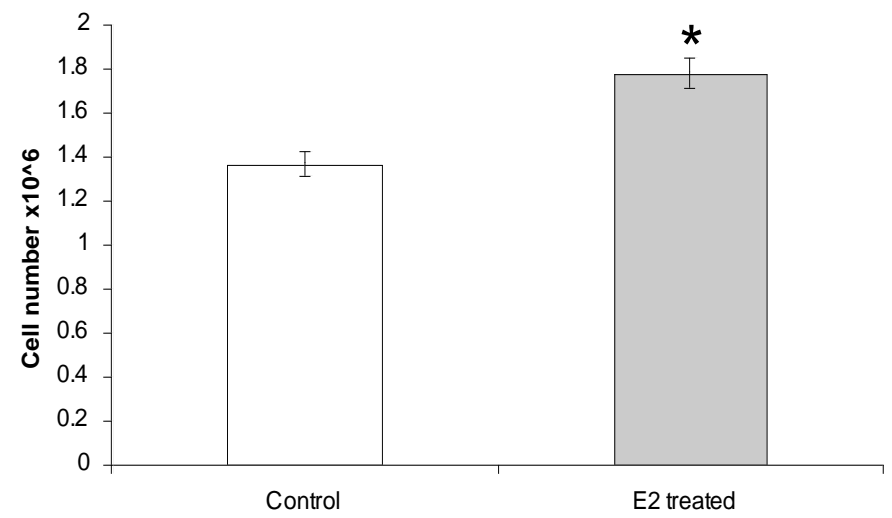

(A)

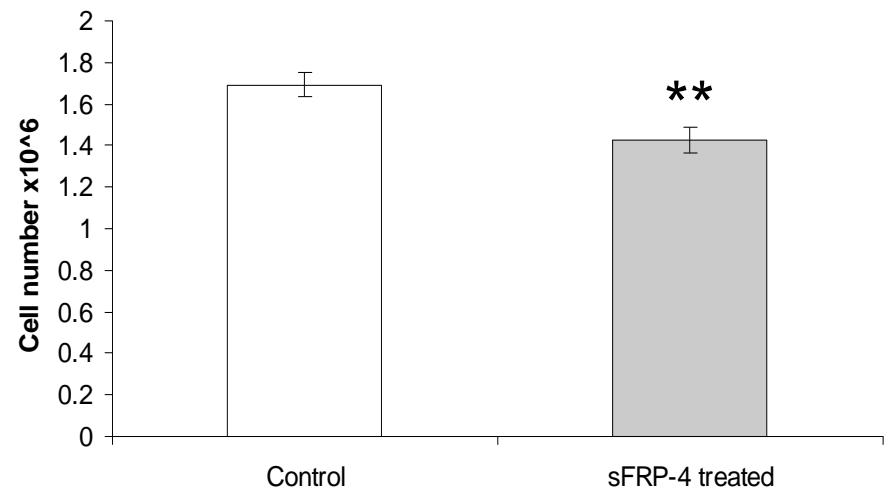

(B)

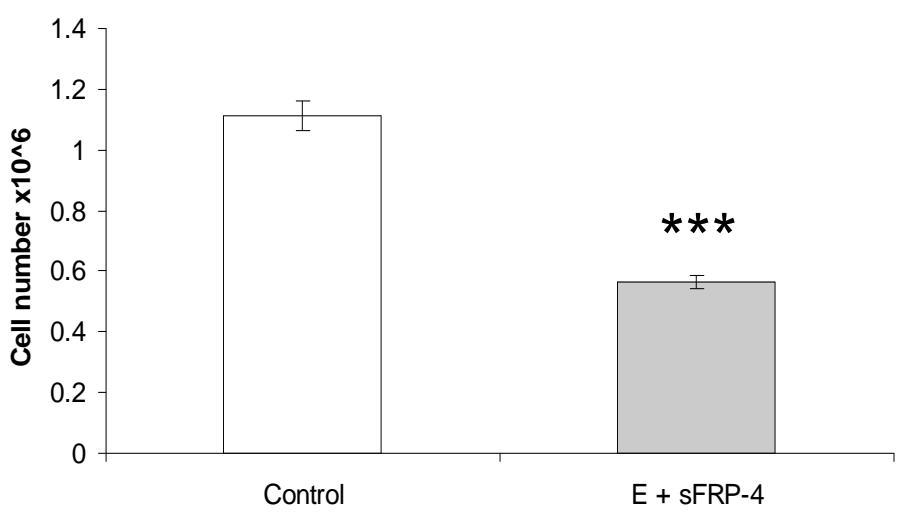

(C)

Figure 1: MCF-7 cell counts following $72 \mathrm{hrs}$ of treatment.

(A) Cells treated with $E_{2}$ for showed a $25 \%$ increase in cell number compared to controls $\left({ }^{*} p<0.001\right)$. (B) Exogenous sFRP-4 treatment resulted in a $15 \%$ reduction in MCF-7 cell number ${ }^{* *} \mathrm{p}=0.003$ ). (C) Combined treatment of $\mathrm{E}_{2}$ and sFRP-4 resulted in a $50 \%$ reduction in MCF-7 cell number $\left({ }^{* *} p<0.001\right)$. Values indicate the average total number of cells as determined by haemocytometer counts \pm SEM. A two-tailed t-test confirmed statistical significance between the two treatment groups $(n=4$ per treatment group).
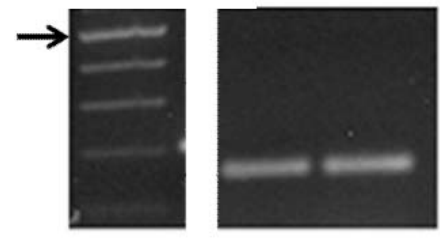

C $\mathrm{T}$

(A)

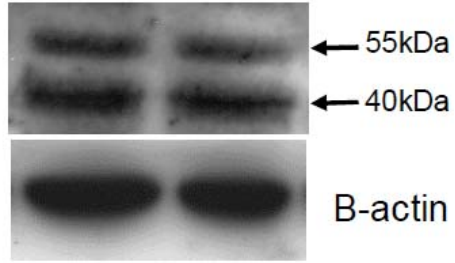

C

(B)

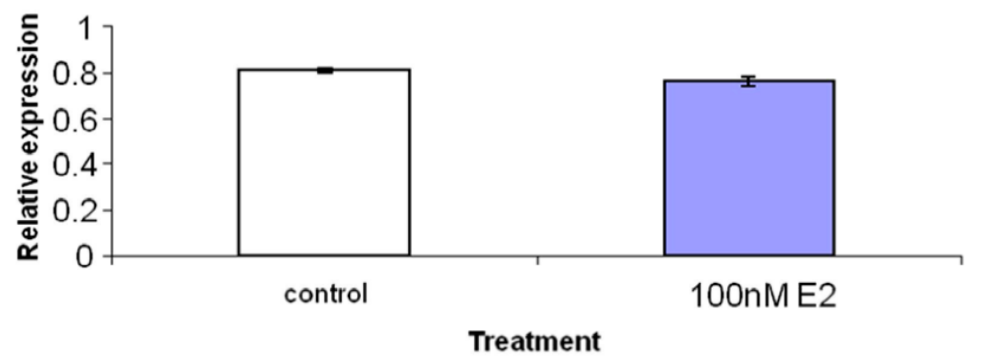

(C)

Figure 2: Effect of $72 \mathrm{hrs}$ of oestradiol treatment on endogenous sFRP4 mRNA and protein levels.

(A) Lane one is a 100 base pair ladder, arrow indicates $500 \mathrm{~kb}$, bands decrease in $100 \mathrm{bp}$ increments. Lane two represents control (C) and $\mathrm{E}_{2}$ treatment (T) sFRP-4 PCR product 110bp in length (dissected from the gel). (B) Western blot demonstrating control (C) and $\mathrm{E}_{2}$ treatment (T) bands of sFRP-4 protein. sFRP-4 antibody detected a 40kDa protein and 55kDa glycosylated sFRP-4 protein and $\beta$-actin (dissected from the gel). (C) Quantitation by densitometry, followed by normalisation to $\beta$-actin protein expression showing no change in sFRP4 protein levels $(n=4)$. 


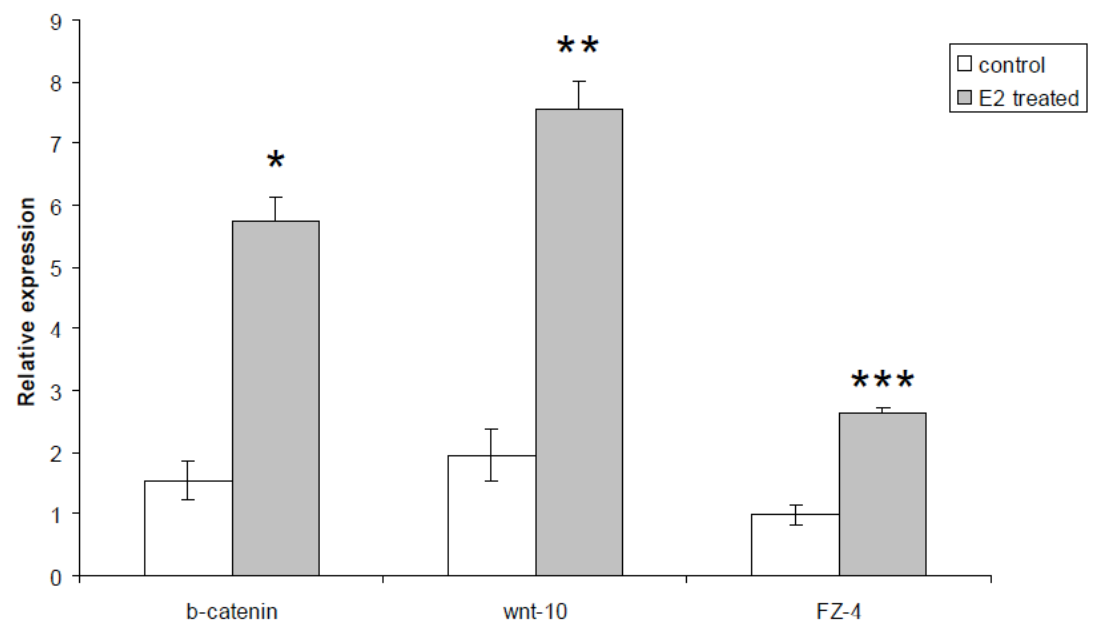

(A)

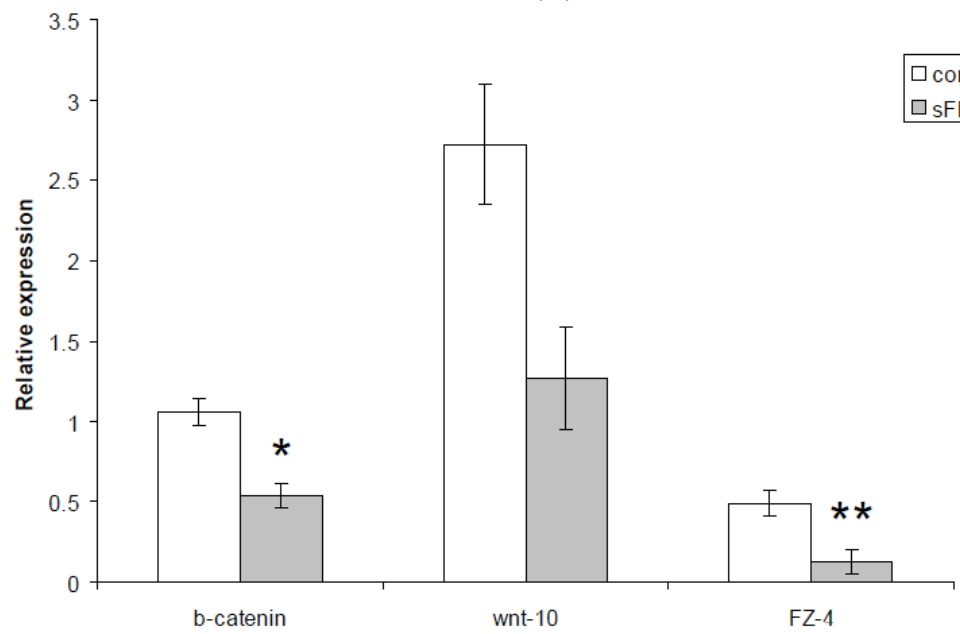

(B)

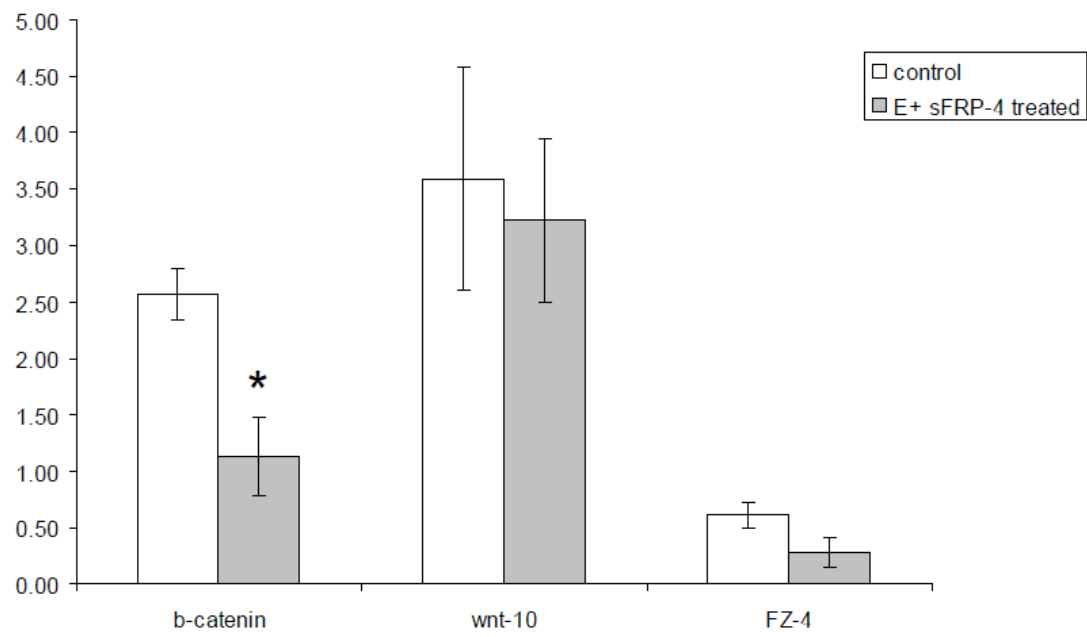

(C)

Figure 3: Quantitation graph of Wnt signalling genes following treatments.

Values represent the mean relative mRNA expression averaged from four samples \pm SEM as determined by comparative quantitation analysis. Values were normalised to the housekeeping gene L-19. Asterisks denote significance as determined by a two-tailed t-test. (A) Quantitation graph of $\beta$-catenin, Wnt-10b, and FZ-4 mRNA following $\mathrm{E}_{2}$ treatment for $72 \mathrm{hrs}$. Treatment resulted in a significant increase in the mRNA of all three genes $(p<0.001$ for all genes). (B) Quantitation of Wnt signalling genes following exogenous sFRP-4 treatment for $72 \mathrm{hrs}$. Treatment caused a significant reduction in both $\beta$-catenin and FZ-4 mRNA $\left(p=0.005, p=0.039\right.$ respectively). (C) Quantitation of Wnt signalling genes following $72 \mathrm{hrs}$ of combined $\mathrm{E}_{2}$ and sFRP-4 treatment. A significant reduction in $\beta$-catenin was apparent following combined treatment $(p=0.001)$. The graphical data represent the mean values \pm SEM of treatment groups $(n=4)$. 
reactions, a single peak was detected on the melt curve indicating the amplification of a single PCR product. Negative controls did not show product amplification (data not shown).

\section{$E_{2}$ Treatment}

Oestradiol treatment resulted in a highly significant four-fold increase in Wnt-10b mRNA, a 3 fold increase in $\beta$-catenin mRNA, and a 2.7 fold increase in FZ-4 mRNA levels by comparison with control $(p<0.001$, Figure 3A).

A reduction in the levels of Wnt-10b mRNA showed a trend towards significance $(p=0.06$; Figure 3B). SFRP-4 treatment resulted in a $50 \%$ reduction in $\beta$ catenin mRNA levels $(p=0.002)$ and also induced a statistically significant $70 \%$ reduction in FZ-4 mRNA levels by comparison with control ( $p=0.03$; Figure 3B).

The combined treatment resulted in suppression of the oestradiol-induced expression of Wnt-10b and FZ4 , but this was not statistically significant for either Wnt$10 \mathrm{~b}$ or $\mathrm{FZ}-4(\mathrm{p}=0.8, \mathrm{p}=0.1$ respectively; Figure $3 \mathrm{C})$. However, a significant reduction in $\beta$-catenin mRNA levels was detected in treated cells $(p=0.01)$.

Whilst we had demonstrated a suppression of expression of both ligand and receptor of Wnt signalling pathway genes by SFRP-4 in MCF-7 cells, it
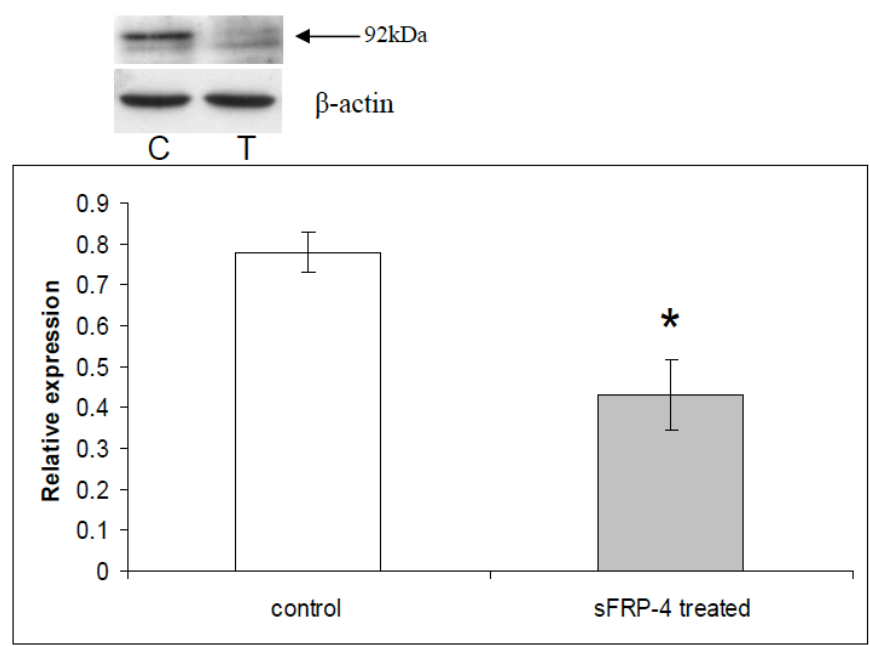

(A) was not clear if this actually resulted in a suppression of Wnt signalling itself. Therefore we investigated this by using an antibody that is specific to the active dephosphorylated form of $\beta$-catenin. A $92 \mathrm{kDa}$ protein band was detected in both control and treated protein samples, and was not detected in no-primary antibody controls (Figure 4). Exogenous SFRP-4 treatment resulted in a highly significant halving of the levels of active $\beta$-catenin protein in MCF-7 cells ( $p=0.01$; Figure 4A), indicating a suppression of the Wnt signalling pathway. A slight, non-significant increase in active $\beta$ catenin protein levels followed combined $E_{2}$ and sFRP4 oestradiol treatment ( $p=0.77$; Figure $4 B$ ).

\section{DISCUSSION}

Oestradiol is able to induce proliferation in the breast cancer cell line MCF-7, and there is evidence that this is mediated through the Estrogen Receptor (ER) acting as a transcription factor controlling the up regulation of genes involved in progression through the cell cycle, such as c-myc and cyclin D1 [12]. Oestradiol also results in the up regulation of selected Wnt genes [13-19], although whether these are under the direct control of the ER has not been demonstrated since the promoter region of these genes does not have Estrogen Response Element sequences.

In prostate cancer cells, sFRP-4 was associated with a better prognosis and, in in vitro experiments,
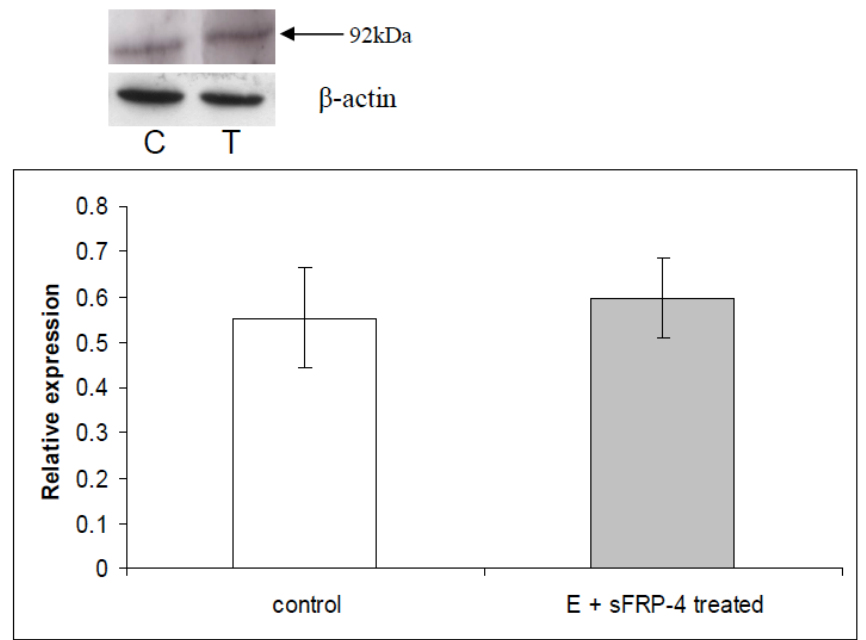

(B)

Figure 4: (A) Active $\beta$-catenin protein levels were measured following $72 \mathrm{hrs}$ of sFRP-4 treatment to determine its effect on Wnt signalling activity. Western blot demonstrating control (C) and treatment $(\mathrm{T})$ band of $92 \mathrm{kDa}$ active $\beta$-catenin and $\beta$-actin (dissected from the gel). Quantitation by densitometry, followed by normalisation to $\beta$-actin protein expression, demonstrated a $55 \%$ reduction in the levels of active $\beta$-catenin protein compared to the control following sFRP- 4 treatment $\left({ }^{*} \mathrm{p}=0.01\right.$; two-tailed t-test). (B) Active $\beta$-catenin protein levels were determined following $72 \mathrm{hrs}$ of combined $\mathrm{E}_{2}$ and sFRP-4 treatment. Western blot demonstrating control $(\mathbf{C})$ and treatment $(\mathrm{T})$ band of $92 \mathrm{kDa}$ active $\beta$-catenin and $\beta$-actin (dissected from the gel). Analysis revealed no significant difference between the levels of active $\beta$-catenin protein in control or combined treated cells $(p=0.77)$. The graphical data represent the mean values \pm SEM of treatment groups $(n=4)$. 
over expression of the SFRP-4 protein was able to down regulate the canonical Wnt signalling pathway [6]. Wnt-mediated signalling leads to an increase in the active form of cytosolic $\beta$-catenin, which in turn translocates to the nucleus where it is involved in coreceptor activity with T-cell factor/Lymphoid enhancer factor (TCF/LEF) transcription factors [18]. This pathway is also associated with enhancing the transcription of Wnt target genes such as c-myc and cyclin D1 [19].

Previous studies have demonstrated that transcription of some Wht genes is induced by oestradiol in MCF-7 cells [11, 13, 14, 16, 17]. However, none of these studies demonstrated whether this up regulation led to an increase in Wnt signalling activity or in cell proliferation. In the present study, oestradiol was able to stimulate proliferation in MCF-7 cells and also increase the expression of selected Wnt signalling pathway genes. We chose Wnt-10b as a candidate Wnt gene as it has been previously reported to be up regulated following oestradiol treatment [11], and has been implicated in human breast cancer [9]. We also examined the expression of FZ-4 since we have previously shown it to interact with sFRP4 in the rodent ovary [20]. RT-PCR analysis demonstrated a significant oestradiol-induced increase in the expression of Wnt$10 \mathrm{~b}(\mathrm{p}<0.001)$, consistent with previous data [11]. In addition, we observed an increase in the expression of mRNA for the Wnt receptor FZ-4 as well as an increase in the downstream Wnt signalling marker $\beta$-catenin $(p<0.001$ for both genes), suggesting that oestradiol was associated with activation of the Wnt signalling pathway in MCF-7 cells. However, we did not observe an increase in the active form of the $\beta$-catenin protein, in contradiction of the mRNA expression seen following oestradiol treatment (data not shown). These results seem to suggest that either oestradiol modulates the expression of active- $\beta$-catenin to steady-state levels, or that oestradiol induces MCF-7 proliferation by a mechanism independent of the Wnt signalling pathway. Alternatively, active- $\beta$-catenin levels may be increasing at a later time point, which may then act to increase cell proliferation but alternative oestrogen signalling pathways are able to induce proliferation earlier. Oestradiol is known to regulate the expression of genes involved in cell-cycle progression such as c-myc and cyclin [12]. It is likely that oestradiol induced MCF7 cell proliferation is brought about by up-regulating the expression of these cell-cycle genes and that the Wnt signalling pathway is either activated at a later timepoint, or is not regulated by oestradiol and plays no part in oestrogen-induced cellular proliferation in MCF7 cells. In support of the antagonistic role of sFRP-4 to oestrogen-driven cell proliferation, it has recently been shown that sFRP-4 is able to down regulate the expression of c-myc and cyclin D1 [21].

As predicted, exogenous SFRP-4 treatment significantly reduced MCF-7 cell proliferation, both under normal growth conditions and when stimulated by oestradiol. When treated with SFRP-4 alone, we observed a decrease in cell proliferation and this was associated with a decrease in both the levels of mRNA and the active form of the $\beta$-catenin protein. This observation is consistent with the proposed model of sFRP-4 antagonism of the Wnt signalling pathway, whereby its binding to Wnt prevents an association with the FZ receptor or formation of a non-functional complex with the $\mathrm{FZ}$ receptor $[4,6,22]$. This implies that, in untreated MCF-7 cells, normal cell growth requires an active Wnt signalling pathway or that this pathway is able to interfere with normal growth. Figure 5A represents a proposed model of the interaction between SFRP-4 and oestradiol on the MCF-7 breast cancer cell line.

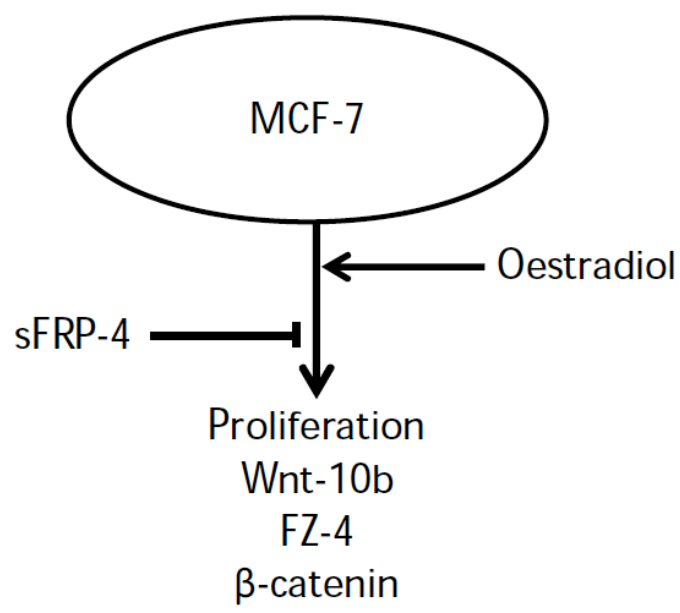

Figure 5: Oestradiol increases MCF-7 cellular proliferation and the expression of Wnt-10b, FZ-4, and $\beta$-catenin at the gene level. However, SFRP-4 is able to block these oestradiol-induced effects.

When oestradiol and SFRP-4 were combined there was a significant reduction in the anticipated effect of oestradiol-induced cell growth in the MCF-7 cells. As there was no significant increase in active $\beta$-catenin protein due to oestradiol treatment alone, it was anticipated that when SFRP-4 was combined with oestradiol, it should still reduce the amount of $\beta$ catenin, as had been seen with SFRP-4 treatment alone; and this would be consistent with SFRP-4 acting through the Wnt signalling pathway. However, this was 
not the case. It is possible that, because the Wnt signalling pathway results in transcriptional regulation of genes that are also transcriptionally activated by oestradiol, there is some overlap of these two pathways. That is, when SFRP-4 down regulates the Wnt pathway, the consequent absence of the TCF/LEF transcription factors results in a less potent response to oestradiol-induced gene expression of cell cycle regulatory genes. This then diminishes oestradiolinduced cell growth.

No change was detected in sFRP-4 mRNA or protein in any of the treatments, suggesting that oestradiol itself does not regulate the expression of sFRP-4 in the MCF-7 cell line. It is not presently known what does increase sFRP-4 expression in normal cells, although it has been associated with apoptosis [23]. More recently, silencing of SFRP-4 via promoter methylation has been demonstrated in $\beta$-catenin deficient mesothelioma cell lines [23]. Re-expression of sFRP-4 in these cells has been shown to not only block Wnt signalling, but to induce apoptosis as well as suppress cell growth [24]; further supporting a growth suppressant and apoptotic role for sFRP-4.

Membranous sFRP-4 expression in prostate cancer has been shown to be predictive of good prognosis, and transfection of SFRP-4 into prostate cancer cells reduces cell proliferation [6]. Our data indicate that sFRP-4 is able to suppress the growth of breast cancer cells and that it may also suppress oestradiolstimulated growth. It would be valuable to determine sFRP-4 expression in a cohort of breast cancer samples, together with other known markers such as Estrogen Receptor status, to ascertain whether sFRP-4 is also associated with a favourable prognosis in breast cancer.

\section{ACKNOWLEDGEMENTS}

The authors thank Dr Jacky Bentel (Royal Perth Hospital) for the generous gift of the MCF-7 cells. A.D. is supported by the Cancer Council of Western Australia.

\section{REFERENCES}

[1] Wolf V, Ke G, Dharmarajan AM, Bielke W, Artuso L, Saurer $\mathrm{S}$, et al. DDC-4, an apoptosis-associated gene, is a secreted frizzled relative. FEBS Lett 1997; 417(3): 385-9. http://dx.doi.org/10.1016/S0014-5793(97)01324-0

[2] Guo K, Wolf V, Dharmarajan AM, Feng Z, Bielke W, Saurer $\mathrm{S}$, et al. Apoptosis-associated gene expression in the corpus luteum of the rat. Biol Reprod 1998; 58(3): 739-46. http://dx.doi.org/10.1095/biolreprod58.3.739
Rattner A, Sabido O, Massoubre C, Rascle F, Frey J. Characterization of human osteoblastic cells: influence of the culture conditions. In Vitro Cell Dev Biol Anim 1997; 33(10): 757-62.

http://dx.doi.org/10.1007/s11626-997-0154-7

[4] Bafico A, Gazit A, Pramila T, Finch PW, Yaniv A, Aaronson $\mathrm{SA}$. Interaction of frizzled related protein (FRP) with Wnt ligands and the frizzled receptor suggests alternative mechanisms for FRP inhibition of Wnt signaling. J Biol Chem 1999; 274(23): 16180-7. http://dx.doi.org/10.1074/ibc.274.23.16180

[5] Abu-Jawdeh G, Comella N, Tomita Y, Brown LF, Tognazzi K, Sokol SY, et al. Differential expression of frpHE: a nove human stromal protein of the secreted frizzled gene family, during the endometrial cycle and malignancy. Lab Invest 1999; 79(4): 439-47.

[6] Horvath LG, Henshall SM, Kench JG, Saunders DN, Lee CS, Golovsky D, et al. Membranous expression of secreted frizzled-related protein 4 predicts for good prognosis in localized prostate cancer and inhibits PC3 cellular proliferation in vitro. Clin Cancer Res 2004; 10(2): 615-25. http://dx.doi.org/10.1158/1078-0432.CCR-0707-03

[7] Saran U, Arfuso F, Zeps N, Dharmarajan A. Secreted frizzled-related protein 4 expression is positively associated with responsiveness to cisplatin of ovarian cancer cell lines in vitro and with lower tumour grade in mucinous ovarian cancers. BMC Cell Biology 2012; 13: 25.

http://dx.doi.org/10.1186/1471-2121-13-25

[8] Jacob F, Ukegjini K, Nixdorf S, Ford CE, Olivier J, Caduff R, et al. Loss of secreted frizzled-related protein 4 correlates with an aggressive phenotype and predicts poor outcome in ovarian cancer patients. PloS One 2012; 7(2): e31885. http://dx.doi.org/10.1371/journal.pone.0031885

[9] Bui TD, Rankin J, Smith K, Huguet EL, Ruben S, Strachan T, et al. A novel human Wnt gene, WNT10B, maps to $12 \mathrm{q} 13$ and is expressed in human breast carcinomas. Oncogene 1997; 14(10): 1249-53. http://dx.doi.org/10.1038/sj.onc. 1200936

[10] Kirikoshi $\mathrm{H}$, Katoh M. Expression of WNT7A in human normal tissues and cancer, and regulation of WNT7A and WNT7B in human cancer. Int J Oncol 2002; 21(4): 895-900.

[11] Kirikoshi H, Katoh M. Expression and regulation of WNT10B in human cancer: up-regulation of WNT10B in MCF-7 cells by beta-estradiol and down-regulation of WNT10B in NT2 cells by retinoic acid. Int J Mol Med 2002; 10(4): 507-11.

[12] Prall OW, Rogan EM, Sutherland RL. Estrogen regulation of cell cycle progression in breast cancer cells. J Steroid Biochem Mol Biol 1998; 65(1-6): 169-74.

[13] Katoh M. Expression and regulation of WNT1 in human cancer: up-regulation of WNT1 by beta-estradiol in MCF-7 cells. Int J Oncol 2003; 22(1): 209-12.

[14] Katoh M. Regulation of WNT3 and WNT3A mRNAs in human cancer cell lines NT2, MCF-7, and MKN45. Int J Oncol 2002; 20(2): 373-7.

[15] Kirikoshi H, Sekihara H, Katoh M. Expression of WNT14 and WNT14B mRNAs in human cancer, up-regulation of WNT14 by IFNgamma and up-regulation of WNT14B by betaestradiol. Int J Oncol 2001; 19(6): 1221-5.

[16] Saitoh T, Katoh M. Expression and regulation of WNT5A and WNT5B in human cancer: up-regulation of WNT5A by TNFalpha in MKN45 cells and up-regulation of WNT5B by beta-estradiol in MCF-7 cells. Int J Mol Med 2002; 10(3): 345-9.

[17] Saitoh T, Mine T, Katoh M. Expression and regulation of WNT8A and WNT8B mRNAs in human tumor cell lines: upregulation of WNT8B mRNA by beta-estradiol in MCF-7 cells, and down-regulation of WNT8A and WNT8B mRNAs by retinoic acid in NT2 cells. Int J Oncol 2002; 20(5): 999-1003. 
[18] Molenaar $M$, van de Wetering $M$, Oosterwegel $M$, PetersonMaduro J, Godsave S, Korinek V, et al. XTcf-3 transcription factor mediates beta-catenin-induced axis formation in Xenopus embryos. Cell 1996; 86(3): 391-9. http://dx.doi.org/10.1016/S0092-8674(00)80112-9

[19] Wong SC, Lo SF, Lee KC, Yam JW, Chan JK, Wendy Hsiao WL. Expression of frizzled-related protein and Wnt-signalling molecules in invasive human breast tumours. J Pathol 2002; 196(2): 145-53.

http://dx.doi.org/10.1002/path.1035

[20] Hsieh M, Mulders SM, Friis RR, Dharmarajan A, Richards JS. Expression and localization of secreted frizzled-related protein-4 in the rodent ovary: evidence for selective upregulation in luteinized granulosa cells. Endocrinology 2003; 144(10): 4597-4606 http://dx.doi.org/10.1210/en.2003-0048

[21] Ford CE, Jary E, Ma SS, Nixdorf S, Heinzelmann-Schwarz VA, Ward RL. The Wnt gatekeeper SFRP4 modulates EMT, cell migration and downstream Wnt signalling in serous ovarian cancer cells. PloS One 2013; 8(1): e54362. http://dx.doi.org/10.1371/journal.pone.0054362

[22] Hou X, Tan Y, Li M, Dey SK, Das SK. Canonical Wnt signaling is critical to estrogen-mediated uterine growth. Molecular Endocrinology 2004; 18(12): 3035-49. http://dx.doi.org/10.1210/me.2004-0259

[23] Drake JM, Friis RR, Dharmarajan AM. The role of sFRP4, a secreted frizzled-related protein, in ovulation. Apoptosis 2003; 8(4): 389-97. http://dx.doi.org/10.1023/A:1024181203729

[24] He B, Lee AY, Dadfarmay S, You L, Xu Z, Reguart N, et al. Secreted frizzled-related protein 4 is silenced by hypermethylation and induces apoptosis in beta-catenindeficient human mesothelioma cells. Cancer Res 2005 1; 65(3): 743-8.

Received on 24-12-2013

Published on 31-01-2014

http://dx.doi.org/10.6000/1927-7229.2014.03.01.1

(C) 2014 McLaren et al.; Licensee Lifescience Global.

This is an open access article licensed under the terms of the Creative Commons Attribution Non-Commercial License (http://creativecommons.org/licenses/by-nc/3.0/) which permits unrestricted, non-commercial use, distribution and reproduction in any medium, provided the work is properly cited. 